\title{
FEEDING THE TRANSCENDENT BODY
}

G. Yúdice

The City University of New York

\begin{abstract}
To eat is to appropriate by destruction; it is at the same time to be filled up with a certain being... When we eat we do not limit ourselves to knowing certain qualities of this being through taste; by tasting them we appropriate them. Taste is assimilation... The synthetic intuition of food is in itself an assimilative destruction. It reveals to me the being which I am going to make my flesh. Henceforth, what I accept or what I reject with disgust is the very being of that existent....

It is not a matter of indifference whether we like oysters or clams, snails or shrimp, if only we know how to unravel the existential signification of these foods. Generally speaking there is no irreducible taste or inclination. They all represent a certain appropriate choice of being.
\end{abstract}

Jean-Paul Sartre !

At first glance, it seems unlikely that contemporary U.S. culture can offer a gastrosophy to match that of other civilizations. Brillat-Savarin's (and Feuerbach's) adage, «You are what you eat), does not throb today with metaphysical significance as it did scarcely two generations ago for Sartre. In the United States, it is indeed a matter of indifference «whether we like oysters or clams, snails or shrimp»; much of the lower priced seafood today is made from other processed fish. Consequently, the differences between particular foods are less important; what really matters is taste itself, laboratory produced flavor. Food as substance gives way to the simulacrum of flavor, which is something that «science» recombines in ever new ways to seduce us to this or that convenience food. As synthetic food replaces Sartre's «synthetic intuition of food», we find it impossible to transcend the brute "facticity" of eating, which is ironically as fake as it is real. We eat substances (that is «real») yet we do not know them as such but as simulations (that is "fake»).

1.- Jean-Paul Sartre, Being and Nothingness (New York: Washington Square Press, 1966). 


\section{G. YÚDICE}

The portrait I've drawn here obviously calls for a reference to Baudrillard, which will come in due time. First, however, it is necessary to reflect a bit more on the changes wrought by the transition to simulation in our (seemingly) most immediate experience: eating. Anthropologists have explained in great detail how entire civilizations defined themselves allegorically through their eating practices. Inclusion or exclusion, symbolic and material exchange, body boundaries, gender, and other identity factors are systematically and most deeply inscribed in the members of a given group through eating practices. Consequently, the metaphysics of most groups is conveyed by these practices. This inscription conditions, for example, how people understand divinity. For the Greeks of Hesiod's Theogony, the rituals of sacrificial cooking and eating, paralleled in agricultural, funereal and nuptial practices, establish a communication between mortals and immortals which paradoxically expresses their incommensurability. In contrast, the Orphic anthropogony makes possible the mystical transcendence of the barrier between gods and humans by rejecting the sacrifice of the official religion.

By refusing this sacrifice, by forbidding the bloodshed of any animal, by turning away from fleshy food to dedicate themselves to a totally «pure» ascetic life - a life also completely alien to the social and religious norms of the city-men would shed all the Titanic elements of their nature. In Dionysus they would be able to restore that part of themselves that is divine ${ }^{2}$.

Since mystical transcendence usually involves some relation to eating or not eating (as in the Orphic cult), it is interesting to ask what are the possibilities of such transcendence in an age of fake fat and microwavable synthetic meals. The mystic engages in a struggle whose reward is nourishing grace. As Saint Teresa says, the soul «finds everything cooked and eaten for it; it has only to enjoy its nourishment" ${ }^{3}$. In our consumer culture, however, such convenience food comes to most of us without the struggle. Unlike the mystic - who is «like a man who has had no schooling... and [yet] finds himself, without any study, in possession of all living knowledge» - we are not graced by any special knowledge. Without negativity - Sartre's «appropria[tion] by destruction»- there is no transcendence. And negativity is precisely what gives the Orphics and mystics like Saint Teresa - often taken as heretics by orthodoxy - with a feeling of power which makes them "master of all the elements and of the whole world" ${ }^{4}$. Transcendence, in these cases, is closely related to contestatory social movements which attempted to invert the power differential between the dominant and the subaltern.

My argument may be met with an objection: that current experiences of people (mostly women) with eating disorders contradict the premise that there are no practices of negativity today. In fact, on the basis of power reversals similar to the ones claimed by mystics, contemporary theorists/practictioners of écriture have rediscovered - and extended to the anorectic - the prototype of an "herethics» beyond the dominant order of things 5 ,

2.- Jean-Pierre Vernant, "At Man's Table: Hesiod's Foundation Myth of Sacrifice», in Marcel Detienne and Jean-Pierre Vernant, The Cuisine of Sacrifice among the Greeks, trans. Paula Wissing (Chicago: University of Chicago Press, 1989), 51.

3.- Saint Teresa of Avila, The Life of Saint Teresa of Avila By Herself (Harmondsworth: Penguin, 1957), 190.

4.- Saint Teresa of Avila, Way of Perfection, tr. E. Allison Peers (Garden City, NY: Image Books/Doubleday, 1964), 137.

5.- Julia Kristeva, «Stabat Mater», in The Female Body in Western Culture, ed. Susan Rubin Suleiman (Cambridge: Harvard University Press, 1986), 99-118. 
or a "mystérique» (fusion of mystic and hysteric) who carves out her own space of enunciation within Western discourse ${ }^{6}$. Following this latter analogy, the mystic's relationship to the inquisitor would be like that of the hysteric before the psychoanalyst who seeks to extract her secrets for the benefit of his doctrine ${ }^{\text {? }}$.

The correlation of mystic/heretic, hysteric and anorectic, however, encounters a serious problem: against what or whom is the anorectic wielding her negativity? Is it just a gender struggle over control of the self, of self-determination, as feminists have claimed? In that case, why do not all women suffer from eating disorders? It seems to me that the issue of control is a necessary but not sufficient condition for the negativity of the anorectic (or the bulimic or the obese woman). Class and/or gender analysis is not enough to account for deeper questions of subjectivity and desire. We are all constrained but some of us go on to become mystics or anorectics. Why? In the most suggestive essay I have read on the topic, Sohnya Sayres argues that those most sensitive to the limitless loss brought on by contemporary society experience, in inverse proportion, a will to greatness and glory:

It is glory that these body-loss-obsessed men and women seek, in making themselves «lost», rapacious glory in society constraining them in rituals around limitless loss. They externalize the return of the repressed in this society which, more than others, is rationalized around the ledger sheets and the accountants of gain, whose most serious intonations are about the «bottom line» --which has remade the "full plate» into the latest idiom for dealing with bad news. One wonders, now, whether the ultimate loss that young people say they are almost sure will be their not too distant future - millennialist, cataclysmic loss - hasn't excited, but sent deeper, those fantasies of messianic rescue lying choked beneath weeds the body imperatives plant in the spirit. Fat and anorectic women and men want to be great, in ways unaccountable... unless we accept the enormity of the unaccountable in this society. 'Then, perhaps, the drama of food and the body can be given a storyteller's innovations, that is, when it is released from explanation and accomodation, all that quantifying, into flights of wit and provocation-released, in other words, from a singular, petty, tale of compulsion into one of sacrifice, mortification, and redemption -into a grander delusion, worthy of the person, worthy of hearing about, worthy of transforming ${ }^{8}$.

I have quoted Sayres at length because she expresses so well the dialectic of loss and

6.- Luce Irigaray, Speculum of the Other Woman, trans. Gillian C. Gill (Ithaca: Cornell University Press, 1985), 191.

7.- «It is easy to learn how to interpret dreams, to extract from the patient'sa associations his [sic] unconscious thoughts and memories, and to practise similar explanatory arts: for these the patient himself [sic] will always provide the textm. Sigmund Freud, Dora: An Analysis of a Case of Hysteria (New York: Collier, 19663), 138.

Freud goes on to observe that the difficult part of interpretation is taking into account unavoidable transferences, «new editions» or replays of fantasies in which the analyst stands in for prior actors. This obenomenon must also be taken into consideration in the very production of the subaltern's text. In the mystic's case, an analysis of the role of confessors and inquisitors is crucial. The role of the mystic and the hysteric should also be considered transferentially in the production of current theories of gendered discourse or behavior (such as eating disorders).

8.- Sohnya Sayres, "Glory mongering: food and the agon of excess", Social Text, 16 (Winter 198687), 94. 


\section{G. YÚDICE}

transcendence which Baudrillard, in turn, will transform into a paean of banality. Baudrillard's hyperreality has no place in it for delusions of grandeur and redemption. Or it may be more exact to say that he does acknowledge grandeur, albeit that of the banal. There is no sense of how people suffer and struggle against that banality. In fact, he has taken the figure of the obese/anorectic, so cherished by feminists, and cast it as the emblem of a society gone awry:

This strange obesity is no longer that of a protective layer of fat nor the neurotic one of depression. It is neither the compensatory obesity of the underdeveloped nor the alimentary one of the overnourished. Paradoxically, it is a mode of disappearance for the body. The secret rule that delimits the sphere of the body has disappeared. The secret form of the mirror, by which the body watches over itself and its image, is abolished, yielding to the unrestrained redundancy of a living organism. No more limits, no more transcendence: it is as if the body was no longer opposed to an external world, but sought to digest space in its own appearance ${ }^{9}$.

Like the social systems in which we live, which are «bloated with information» and deprived of significance, Baudrillard's obscene obese/anorectic body has lost the "principle of law or measurey that supported once it. Its meanings and representations have also transmuted into metastatic self-replication. History is now seen as a succession of devourments which, along with ideology and politics, reach a saturation point that knows no limits; metastasis encompasses everything, nothing is at odds with it, nothing can transcend it. And as every condition has its symptomatic figuration, Baudrillard's obscene hyperreality finds its «perfect confirmation and ecstatic truth» in the obscene body, which «instead of being reflected, captures itself in its own magnifying mirror» 10.

Europe has long served as the proscenium for the death of the subject and history; the allegory of the death of life could have no other setting, of course, than the United States, home of those exemplary killers of experience: fast food, fast sex and genetic engineering.

I would like to talk about an anomaly - that fascinating obesity, such as you find all over the U.S., that kind of monstruous conformity to empty space, of deformity by excess of conformity that translates the hyperdimension of a sociality at once saturated and empty, where the scene of the social as well as that of the body are left behind "I.

In the grand allegorical tradition, Baudrillard offers us a new reading of the bodyas-microcosm-of-the-world. This body is not a temple, nor a machine, nor a holistic organism. It is the obscene body without order, whose cells have gone rampant in "cancerous metastesesy that parallel the useless flow of information in the postmodern world. If disease was once interpreted as lesion (the body as machine model) or as adaptive response to stress (the organic model) ${ }^{12}$, Baudrillard's viral analogy construes it as coex-

9.- Jean Baudrillard, "The Obese», in Fatal Strategies, trans. Philip Beitchman and W. G. J. Niesluchowski (New York: Semiotext(e)/Pluto, 1990), p. 27.

10.- Baudrillard, «The Obese», 34.

11.- Ibid., 27.

12.- For an account of the «body as » cognitive schemas which underwrite these different accounts for disease, see Mark Johnson, The Body in the Mind. The Bodily Basis of Meaning, Imagination and Reason (Chicago: University of Chicago Press, 1987), 126-36. 
tensive with «lifem. It is, however, a life with no rhyme or reason other than the momentum/inertia of self-replication: "Quite simply, there is no life any longer [...] but the information and the vital functions continue ${ }^{13}$ \%.

The body registers the «useless and wasteful exhaustion» of all systems in the figure of the obese (satiation) and/or the anorectic (inertia). On this view, the obese and the anorectic are neither the victims of some accident whose results can be reversed by altering a body part («removing portions of the stomach or intestine so that only small amounts of food could be eaten or digested») nor the adaptation to stressful «environmental factors (exercise habits, self-image, personal relationships, work pressures, etc.)»14. They are, rather, the embodiment of permanent crisis: inflation, overproduction, unemployment, nuclear threat, anomaly, to sum up.

Yes. At first sight, the example seems irrefutable. What better emblem of the empire of the senseless, useless waste of resources than the insatiable obese and anorectic of (North) America, driven to passivity, apathy and indifference by the infinite choice of consummables? ${ }^{15}$ In a very insightful essay in which he mines the contradictions between capitalism and transgression, Octavio Paz notes that by rigorously applying the norm of the «limitless production of the same», North American society succeeded in coopting the erotic and gastronomic rebellions of the $60 \mathrm{~s}$ into slogans for the media ${ }^{16}$ :

The popular character of the erotic revolt was immediately appreciated by the mass media, by the entertainment and fashion industries. For it is not the churches nor the political parties, but the great industrial monopolies that have taken control of the powers of fascination that eroticism exerts over men. [...] What began as a[n erotic] liberation has become a business. The same has happened in the realm of gastronomy; the erotic industry is the younger sister of the food industry. [...] Private business expropriates utopia. During its ascendancy capitalism exploited the body; now it has turned it into an object of advertising. We have gone from prohibition to humiliation ${ }^{17}$.

Paz did not fathom the extent to which gastronomy was being appropriated by industry. Today it no longer takes a major intellectual to understand that food is subject to the same image manipulation as all other commodities. Flavor, color, consistency, texture, smell, caloric and nutritional value, even genetic composition are all engineered to seduce each and every consumer. Food has, in effect, become a simulacrum which the omnivorous psyche of North America cannot get enough of even at the ever quicker pace of production, preparation and consumption.

With the ever-accelerating pace of life, the act of eating -once a leisurely undertaking synonymous with pleasure and social interaction- has been reduced

13.- Jean Baudrillard, "The Anorectic Ruins», in Jean Baudrillard, et al., Looking Back at the End of the World, eds. Dietmar Kamper and Christoph Wolf, trans. David Antal (New York: Semiotext(e) Foreign Agents Series, 1989), 39.

14.- Johnson, The Body in the Mind.

15.- Cf. Lena Williams, "Free Choice: When Too Much Is Too Much $\dagger$, The New York Times (2/14/90): Cl, C10.

16.- For a recent account of the radical potential and eventual cooptation of the "gastronomic counterculture», see Warren Belasco, Appetite for Change: How the Counterculture Took On the Food Industry, 1966-1988 (New York: Pantheon, 1990).

17.- Octavio Paz, «Eroticism and Gastrosophy», Daedalus, 101, 4 (1972): 81. 


\section{G. YÚDICE}

to a necessary function not unlike shaving or refueling the car, in the view of food manufacturers, social scientists and others ${ }^{18}$.

The loss which Sayres refers to above, is not only the erosion of the supreme experience of transcendence; even the petty pleasure of eating a cheeseburger fades as the milk fat is replaced by vegetable oils (if not a cellulose-based fat substitute) and the grill gives way to the microwave. Even the singe marks are painted on the frozen patty. Increasingly, we consume in solitude; a recent Gallup poll found that only $1 / 3$ of North American adults dine at home in the company of others ${ }^{19}$. By 1992, cars will come equipped with microwaves so we can consume on our way to and from work ${ }^{20}$. And moms are now free to stay at work as children from two years of age and older pop $M y$ Own Meals or Kid Cuisine in the microwave 21.

«Freedom» seems to come so easily, there is no struggle; there isn't even an "other» to struggle against; the values once instilled by preparing our own food and eating together as a family have given way to a new ethos: flip the switch. For Baudrillard, we become the simulacra we consume, hostages uof a fate that is fixed, and whose manipulators we can no longer seem ${ }^{22}$. We are thus levelled to a homogeneous status of victim and perpetrator. None of us and all of us are to blame. A very convenient fiction that furthers the hegemony of those whom he refuses to see.

It is hardly a secret that a handful of transnational corporations - General Foods, Nestle, Monsanto, R. J. Reynolds, etc.- control agribusiness, from production to shipping, processessing, distribution and marketing. It is no secret that this control puts those "disappeared» others who produce what we consume in the most onerous of conditions: twelve hours of work for a couple of dollars in Central America, a situation which has been getting worse under the Reagan and Bush administrations. Nor is it a secret that people here in the United States are also going hungry due to increases in prices and the erosion of welfare benefits by inflation and cutbacks ${ }^{23}$. Add to these «secrets» the devastation of the world's natural resources for the ingredients and packaging of fast and convenience foods ${ }^{24}$, and you get a good sense of the loss, the other side of the simulacrum.

18.- Dena Kleiman, «Fast Food? It Just Isn't Fast Enough Anymore», The New York Times (12/6/89): $\mathrm{A} 1, \mathrm{Cl} 2$.

19.- The September 1989 Gallup poll is cited in Kleiman, p. C12.

20.- Ibid.

21.- Denise Webb, «Eating Well», The New York Times (2/14/90): C8.

22.- Baudrillard, «The Obese», 35.

23.- Dr. DeHavenon, director of research for a private research committee on welfare benefits stated that the "'. asic welfare grant in New York had gone up only 28 percent since 1969, while prices have increased 180, percent, and that cutbacks in the foodstamp program have contributed to the problem». Richard Severo, «East Harlem Study Shows Hunger Worsens», The New York Times (6/3/84): 46 .

24.- Books and articles on transnational control of agribusincss and destruction and contamination of resources is voluminous. Among them are: Joseph N. Beldon, et al. Dirt Rich, Dirt Poor. America's Food and Farm Crisis (London: Routledge and Kegan Paul, 1986); James Danaher, «U.S. Food. Power in the 1990sm, Race \& Class, 30, 3 (1989); Susan George, How the Other Half Dies. The Real Reasons for World Hunger (Washington, DC: Institute for Policy Studies, 1977); Frances Moore Lappé and Joseph Collins, World Hunger. Ten Myths (San Francisco: Food First, 1982); James O'Connor, «Uneven and Combined Development and Ecological Crisis: A Theoretical Introduction», Race \& Class, 30, 3 (1989); N. Shanmugaratnam, "Development and Environment: A View From the South», Race \& Class, 30, 3 (1989); Jill Torrie, Banking on Poverty: The Impact of the IMF and World Bank (San Francisco: Food First, 1986). 


\section{FEEDING THE TRANSCENDENT BODY}

Baudrillard's allegory is a rather simplistic correlation of digestion and information processing, which permits passing over the intense battles which are currently waged in the medium of the body. The body is not simply the screen on which the rampant exchange of information and images is captured; it is, rather, the battleground in which subjects are constituted, contradictorily desiring and rejecting prescribed representations. Baudrillard does not even recognize this struggle; in his hyperreal world there is only conformity, an unproblematic consensus in which not only consumers but even terrorists collaborate.

Since, for Baudrillard, experience has disappeared his allegorical viral body is raceless, classless, genderless, ageless; it has no identity factors. Consequently, and contrary to the reported experience of most people, it is not shaped by the ways particular social formations interpellate specific bodies through these factors. The struggle of women against what Kim Chernin has called the "tyranny of slenderness" is a good example of how some bodies and not others are made to incarnate certain social contradictions on the basis of gender ${ }^{25}$. Obesity and anorexia, then, do not correlate so much with the the self. replication of information but rather with the control of bodies. In the United States, control of the body by means of «idealizing» representations (consumerism and the media) and ever more frequently through outright coercion and the interdiction of counterrepresentations (the conservative offensive) have pretty much replaced prior forms of maintaining hegemony. For Susie Orbach, the anorectic's «hunger strike», is a metaphor for this struggle of representation ${ }^{26}$. But this is a struggle to which Baudrillard seems quite indifferent; in his view, we have already lost and there is no way of transforming that loss into the "grander delusion" of something worthy (Sayres). Why play the deluded fool that resists the body snatchers; the sooner we yield the sooner we can all enjoy the obscenity.

Baudrillard bears a resemblance to the confessors of the mystics. They arbitrated between those mystics inspired by God and those inspired by the devil. Baudrillard adjudicates between mere traditional experiences of transcendence ( $T$ This is not Georges Bataille's excessive superfluity") and the sublime banality of the hyperreal and hypertelic, which know «no other end than limitless increase, without any consideration of limits» 27. As such he embodies Jameson's description of the sublime hysteric, hungering after figurations (simulacra) of the other of capitalism once Nature and Being have been eclipsed 28 . Control and limits, nonetheless, continue to be important, even constitutive, for Baudrillard because his fascination with obscenity, like all appreciations of sublimity, plays off the point at which limits can no longer be controlled. Hence, the body, not figuratively but (hyper)really embodies the world. In becoming image, it matches the mediatedness that is the world.

In one respect I think that Baudrillard has chosen a very apt allegory of sublime banality in the obese/anorectic body. In some sense, women with eating disorders are today's mystics; the ethical substance of their search for transcendence may not be sublime in the conventional sense but they occupy a privileged space in a world that has depleted

25.- Kim Chernin, The Obsession. Reflections on the Tyranny of Slenderness (New York: Harper and Row, 1981).

26.- Susie Orbach, Hunger Strike: The Anorectic's Struggle as a Metaphor for our Age (New York: Norton, 1987).

27.- "The Obese», 31.

28.- Fredric Jameson, «Postmodernism, or The Cultural Logic of Late Capitalism», New Left Review, 146 (July-August 1984): 77. 


\section{G. YÚDICE}

its divine incommensurabilities. In other words, today's incommensurability is the representational space of their own bodies, which they struggle to control. Most analyses of eating disorders take a psychoanalytic and/or feminist stance according to which the obese or the anorectic woman strives to manage the double binds of prescriptions of slenderness and consumption, will and abandon to instant gratification.

Susan Bordo summarizes very well the «deeper psycho-cultural anxieties... about internal processes out of control - uncontained desire, unrestrained hunger, uncontrolled impulse». Bordo posits the bulimic as the embodiment of the «contradictions that make self-management a continual and virtually impossible task in our culture» ${ }^{29}$. The bulimic, she argues, plays out on her body the «incompatible directions» of consumerist temptations and the freedom implied in the virile image of a well-muscled slender body. If consumerism makes the feminine image central to our culture (because of its seductive power, Baudrillard would argue ${ }^{30}$, such that even literary theorists can claim that writing is a subversive feminine activity, it nevertheless requires repressing the very materiality or essential nature, as Kim Chernin puts it, of women's bodies ${ }^{31}$. For Chernin it is repression that transforms the body into an «alien» that may in momentary lapses of control rear its head and return with a vengeance.

But clearly it is also the relatively non-repressive introjection of images that produces this alienation. In contrast to Chernin, I would argue that alienation is not the loss of an essential nature; in an age in which people believe and practice making themselves over, the traditional notion of essence becomes absurd. It is, rather, a question of remaking not only oneself but even more importantly the social formation that attributes value to the "nature» that we embody. It is this capacity which so many people experience as lost. Sociality can then be understood as the struggle for value, which entails the recognition of diverse «natures») and the social ministration to their needs. Elsewhere I have elaborated on how such ministration responds to the struggle over needs interpretation, which is basically a struggle over the representation of our «nature», be it in the form of gender, ethnicity, age, and so on ${ }^{32}$.

On this view, the materiality that defines us need not be understood monolithically as the rejected archaic maternal body which according to Kristeva undergirds the radical limit-experience of abjection. It seems to me that the very notion of archaic is remade in the image of the media. The current «fat taboo» may in fact hark back to the separation process performed by traditional dietary and other ritual prohibitions, although today fat food and fat image are hypostatized in our consciousness:

[Such prohibitions] keep a being who speaks to his God separated from the fecund mother... [the] phantasmatic mother who also constitutes, in the specific history of each person, the abyss that must be established as an autonomous (and not encroaching) place and distinct object, meaning a signifiable one, so that such a person might learn to speak ${ }^{33}$.

29.- Susan Bordo, «Reading the Slender Body», in ... p. 88.

30.- Cf. Jean Baudrillard, The Ecstasy of Communication (New York: Semiotexte, 1988).

31.- Chernin, The Obsession, 45-55.

32.- Juan Flores and George Yúdice, «Living Borders/Buscando América. Languages of Latino Self-Formation", Social Text, 24 (1990).

33.- Julia Kristeva, Powers of Horror. An Essay on Abjection (New York: Columbia University Press, 1982), 100. 
Dietary taboos, however, are increasingly becoming a matter of image manipulation. For example, you can still have your cake and eat it too if you're kosher and desire to eat a slice of (simulated) cheesecake after your pastrami on rye at Katz's Delicatessen, that exemplary custodian of Glatt kosher cuisine. Taboo only makes a difference if you can have your cake and not eat it. Does this mean, then, that in a culture of simulation there are no longer ways of distinguishing the abject from the proper object, thus making the will to transcendence irrelevant?

Rather than accept this premise, it seems preferable to me to explore Mary Douglas's notion that anxiety around bodily boundaries signals significant social change or crisis. What and how we eat undergirds other kinds of social boundaries (marking off the difference between purity and pollution, inside and outside, etc.). As such, dietary practices function as a support for the cognitive systems by which cultures make sense of the world. They wire, so to speak, the way in which our bodies interface with the media of signification ${ }^{34}$. This is what Kristeva mcans when she says, in the passage quoted above, that the maternal body archaically establishes radical negativity, which she then goes on to fetishize, in the metaphor of the abyss, as the very condition of speech. But this is to reduce speech to the verbal and practice to negativity, thus privileging avant-gardist practices in the registers of high aesthetics. The recognition of mediation as necessary for our survival does not have to lead, however, to a Baudrillardian celebration of the simulacrum:

Seduction as an invention of stratagems, of the body, as a disguise for survival, as an infinite dispersion of lures, as an art of disappearance and absence, as a dissuasion which is stronger yet than that of the system ${ }^{35}$.

The struggle over representation as I have briefly sketched it out does not fetishize the disguise nor lead one to confuse the high aesthetic appropriation of pop and mass culture with political effectivity. Its political value is more complex than the simple play of quotes or intertextuality. It challenges institutional control over images but not by remaining totally within the frame of the institution as, say, in the work of Cindy Sherman or Sarah Tuft. In a recent video, Don't Make Me Up (1986) ${ }^{36}$, Tuft seeks to reframe commercial images of women's bodies variously eating, exercising, courting, etc. by overlaying them with critical comments (e.g., «I just won't buy this pack of lies») and by juxtaposing them with images that give a critical twist to the prescription of thinness, such as photographs of emaciated concentration camp prisoners. The images succeed each other rapidly to the beat of a rap song, a vehicle which should have helped give the video a more contestatory tone. However, due to the blandness of the voice (this is no Public Enemy) and the too rapid succession of images (which does not leave enough time to register that some of the images run counter to commercial idealizations), the video does not succeed in raising the consciousness of those who aren't already convinced. Even the convinced tend to enjoy it for its display of «idealized» bodies and its danceable rhythm. The overall effect is the very opposite of its punch line: «I must get free of the

34.- See Mary Douglas, Purity and Danger. An Analysis of Concepts of Pollution and Taboo (London/Boston/Henley: Routledge \& Kegan Paul, 1969), 121. See also Kristeva, 69.

35.- Baudrillard, The Ecstasy of Communication, 75.

36.- This video was included in "Unacceptable Appetites", a video program at Artists Space (2/25$4 / 2 / 88$ ) curated by Micki McGee. McGee's catalogue essay is an invaluable resource for the interpretation of interrelations of images of food and eating, feminine identity and the dialectic of control and self-determination. 


\section{G. YÚDICE}

messages being fed to me». With a better sound track, it would not be a surprising clip on MTV.

David Cronenberg's Videodrome (1983) also flirts with the possibility of resistance to the implosion of reality into media imagery. But the video images which the hero/victim Max Renn consumes end up consuming him, absorbing him into the image world of video. As head of a small TV station in search for seductive programming, he views a pirated snuff movie which, unbeknownst to him, inoculates him with electronic frequencies that produce a brain tumor that takes control of body and mind. A vagina-like VCR slot opens up in Max's abdomen in which video cassettes with behavioral programming are inserted by the agents of Videodrome, a transnational corporation engaged in a conspiracy to take control of North America in order to counter the debilitating effects of liberal ways of life. Through the video-mediated intervention of Professor Brian Oblivion, a thinly disguised combination of McLuhan and Baudrillard, Max turns the weapon of his «new flesh» against Videodrome. The film ends with Max killing off his old flesh and fusing with the «new flesh» of the video monitor, whose screen stretches out like a pregnant belly. Professor Oblivion's daughter and assistant Bianca tells Max that he has «become the video word made flesh». Mysticism and abjection thus collapse onto the flesh of mediation.

Despite the evident retaliation which the protagonist carries out, Videodrome is less about resistance or rearticulation of society than a Baudrillardian celebration of the apocalyptic collapse - or implosion - onto the surface of the image. This implosion, however, does not collapse the conventions of capitalist, patriarchal culture. The hero is the proverbial white middle class male, female figures are portrayed as the usual stereotypes (whore or primal medium-mother), there is no solidary consciousness on the part of the very few racial minorities or otherwise marginal characters, like the homeless man whose begging is facilitated by the «dancing monkey» of a TV monitor on a leash. The closest to a political intervention is Professor Oblivion's video version of a soup kitchen: The Cathode Ray Mission, where patrons are given a diet of TV frequencies rather than food. They are being prepped, it is suggested, for taking on the «new flesh» of electronic mediation.

E. Ann Kaplan makes a half-hearted attempt to argue for some «progressive» content in Videodrome ${ }^{37}$. It is not, for example, typical of mainstream media in presenting the abject in the form of a male body. Secondly, the body is made androgynous by the vagina-like slot that opens up in Max's belly and the placenta-like covered handgun that he sticks in and out of the slot. As a feminist, Kaplan interprets "postmodern discourse of this kind» as an implicit critique of the "horror of technology that deforms all bodies and blurs their gender distinction» ${ }^{38}$. Also as a feminist, however, Kaplan draws some positive conclusions from the androgynizing blurring of distinctions effected by rock videos:

Many rock videos have been seen as postmodern insofar as they abandon the usual binary oppositions on which dominant culture depends. That is, videos are said to forsake the usual oppositions between high and low culture; between masculine and feminine; between established literary and filmic genres; between past,

37.- E. Ann Kaplan, «Feminism/Oedipus/Postmodernism: The Case of MTV», in Postmodernism and its Discontents. Theories, Practices, ed. E. Ann Kaplan (London/New York: Verso, 1988).

38.- Ibid., 40. 


\section{FEEDING THE TRANSCENDENT BODY}

present and futurc; between the private and the public sphere; between verbal and visual hierarchies; between realism and anti-realism, etc. This has important implications for the question of narrative as feminists have been theorizing it, in that these strategies violate the paradigm pitting a classical narrative against an avantgarde anti-narrative, the one supposedly embodying complicit, the other subversive, ideologies. The rock video reveals the error in trying to align an aesthetic strategy with any particular ideology, since all kinds of positions emerge from an astounding mixture of narrative/anti-narrative/non-narrative devices ${ }^{39}$.

The hybridity, ambiguity and lack of a «fixed identity» which Kaplan and cultural historians of video like Roy Arms attribute to the medium ${ }^{40}$, are also terms that Kristeva has used to describe the abject. They both are about "the breaking down of a world that has erased its borders» ${ }^{41}$. In this sense, Cronenberg's Videodrome is not so much a metaphor or allegory of the abject but rather the cinematic demonstration that experience is the consumption of media, that the body of mediation is the body of the real («whatever appears on the television screen emerges as raw experience for those who watch it»). If the reality of mediation in Videodrome is its embodiment in "uncontrollable flesh", for Kristeva the blurring of the corporeal limits established by food, waste, and signs of sexual differentiation produces "uncontrollable materiality". In both cases there is an avowal of the death drive ( TTo become the new flesh [of mediation] first you have to kill off the old [demarcated] flesh») and a disruption of identity («I don't know where I am now. I'm having trouble finding my way around»).

This dissolution of identity, furthermore, takes place for Kristeva in relation to the mother's body, the "place of a splitting», «a threshold where 'nature' confronts 'culture'» 42. In Videodrome, Max's dissolution (which is concomitant to the vaginal stigmata that opens up in his belly) and his transformation into the "new flesh» take place in the medium of video, a body on which viewers "gorge themselves» and with which Max fuses in an inverse birth (i.e.; when he sticks his head into the «pregnant» TV monitor). In fact, both maternal body and mediation come together in Kristeva's positing of the mother as the agency that maps or formats the body and readies it for the mediation that is language.

[Maternal authority] shapes the body into a territory having areas, orifices, points and lines, surfaces and hollows, where the archaic power of mastery and neglect, of the differentiation of proper-clean and improper-dirty, possible and impossible, is impressed and exerted. It is a 'binary logic', a primal mapping of the body that I call semiotic to say that, while being the precondition of language, it is dependent

39.- Ibid., 36.

40.- «[It] is a form which is both fascinating and self-contradictory: distributed in video format but shot on film, free-wheeling yet constrained by its advertising function, visually innovative yet subordinated to its sound track, an individual artefact which is parasitic on a separate and commercially more important object (the record or the cassette), a part of the distinctive youth culture that needs to be played through the equipment forming the focus of family life. Despite - or perhaps because of - these contradictions, the pop video points to the new potential of video as a medium in its own right."

Roy Armes, On Video (London/New York: Routledge, 1988), p. 158.

41.- Kristeva, 4.

42.- Julia Kristeva, «Mother hood According to Giovanni Bellini», in Desire in Language. A Semiotic Approach to Literature and Art (New Yorkk: Columbia University Press, 1980), 238. 


\section{G. YÚDICE}

upon meaning, but in a way that is not that of linguistic signs nor of the symbolic order they found ${ }^{43}$.

Can we call this experience a transcendence? And what does it achieve? If we consider mysticism, we readily see, as in Saint Teresa's writings, that transendence is experienced as a freedom which empowers the subject through infinite expansion:

When a soul sets out upon this earth, He does not reveal Himself to it, lest it should feel dismayed at seeing that its littleness can contain such a greatness; but gradually $\mathrm{He}$ enlarges it to the extent requisite for what He has set within it. It is for this reason that I say He has perfect freedom, since He has power to make the whole of this palace great 44 .

But the mystic's experience is not totally determined by a God from the outside. Selfmastery through prayer and meditation are the preconditions for fashioning a space without which the divinity could have no presentation. Perhaps Saint Teresa's best known claim for the constitutive capacity of the mystic is the metaphor of the silkworm in The Interior Castle. Through speech-prayer (oración), the nuns spin their interior dwellings, like the silkworm its cocoon. In language that recalls Heidegger's, Saint Teresa describes these dwellings as the resting place of the nuns, the space of their death. It is also the space of the Godhead, the "new [mystic] flesh». St. Teresa would seem to be on the verge of heresy here for she claims that it is the nuns who can place or withdraw God at will since it is they who «fabricate the dwelling which is God so that they might live/die in it 45. "[The Lord] becomes subject to us and is pleased to let you be the mistress and to conform to your wills ${ }^{46}$.

I have brought up the case of St. Teresa because, as in Videodrome, transcendence takes the form of the subject embodying the medium. For both the mystic (Saint Teresa) and the subject of the "new flesh» (Max Renn) phenomenality is overcome not by reaching beyond it but by collapsing what would otherwise be the "supersensible idea" of the sublime onto appearance or image itself. The "new flesh» is the collapse of idea and body as medium, a collapse which, in Saint Teresa's words, provides «free[dom] from earthly things... and master[y] of all the elements and of the whole world» ${ }^{47}$. In Saint Teresa's case it is not too difficult to understand how the dialectic of freedom and mastery enabled this marginal and subaltern person (woman, «new Christian», eccentric) to negotiate a measure of power in a hierarchical and patriarchal society overseen by the all pervasive scrutiny of the Inquisition:

You will not be surprised, then, sisters, at the way I have insisted in this book that you should strive to obtain this freedom. Is it not a funny thing that a poor little nun of St. Joseph's should attain mastery over the whole earth and all the elements? ${ }^{48}$

43.- Kristeva, Powers of Horror, 72.

44.- Saint Teresa of Avila, Way of Perfection, 189.

45.- «Que Su Majestad mesmo sea nuestra morada, como lo es en esta oración de unión, labrándola nosotras! Parece que quiero decir que podemos quitar y poner en Dios, pues digo que Él es la morada, y la podemos nosotros fabricar para meternos en ella.»

Las moradas (The Interior Castle of the Dwellings of the Soul) (Madrid: Espasa-Calpe, Col. Austral, 1964), 72.

46.- The Way of Perfection, 175.

47.- Way of Perfection, 136-37.

48.- Ibid., 137. 


\section{FEEDING THE TRANSCENDENT BODY}

The influence of St. Catherine of Siena over popes and monarchs is also well known. Through radical fasting both of these saints brought their bodies to extreme states of abjection that resulted in death. But abjection gave them a power over and above representation that the authorities of the Inquisition felt obliged to recognize and to channel in ways that did not topple the institution, for both saints were also reformers.

Can the same be said for either Max Renn or the anorectics of today? What is their power, if any? Can they, like the mystics, transform their abjection into transformative power? I think not. Sure, the theme continues to have some cachet within literary studies where anorectics like Emily Dickinson are hailed as rebels against patriarchy. The problem, however, is that the thematics of abject rebellion have been conceived in relation to high art. Kristeva's examples - Dostoyevsky, Lautréamont, Proust, Artaud, Kafka, Célineare not easily transferred to the mass mediated reality of today, say Roseanne Barr. Why is that?

In the first place, Kristeva's privileged abjects are all avant-gardists and as we know the lynchpin of the avant-garde was to transform life by recourse to an aesthetic modality that had its raison d'être in bourgeois modernity. Secondly, since aesthetics is thoroughly commodified as mass culture absorbs it, it can hardly be the means for a transformation of life in the service of emancipation. To collapse idea and body onto medium, then, implies a commodification which is not sufficiently thematized in Videodrome. Can the «new flesh» really be other than commodified flesh? The references to simulated foods in an earlier section of this essay only reinforce the idea that mass mediated simulation is in fact transforming us all into commodified media. The rebellion of the anorectic counters this but only at the cost of dysfunction or death, that is, disembodiment.

Is there, then, any other politics of representation that can prove more successful? One attempt is the acceptance of the premise that we too are simulations but that we can rearliculate the way we have been constituted. This takes at least two forms: one which continues to accept that an autonomous aesthetics can have an impact on the culture. For example the work of Cindy Sherman or the Sarah Tuft's video Don't Make Me Up. Ultimately, I think these are failed attempts not because they work with commodified images but rather because they still accept the confines of aesthetic institutionalization. On the other hand, the aesthetic practices involved in identity formation among ethnic groups and certain social movements like gays and lesbians do not distinguish between the market, the street, the university and the gallery. The work of such groups as ACTUP and Guerrilla Girls as well as many other groups working in collaboration with particular constituencies stake out new public spaces for re-embodying media and struggle within and against the dominant media to reconfigure the institutional arrangements of our society. Safe-sex videos, for example, project new ways of eroticizing the body in an age increasingly defined by a new puritan fundamentalism (which includes the anti-abortion movement, reinforced homophobia, and the War on Drugs).

It is not enough, in the face of this offensive, to reshuffle representations. If this were all to contemporary cultural politics, Baudrillard would indeed be correct in understanding any practice as the body «digest[ing] space in its own appearance» ${ }^{49}$. As regards the consumption of food, the age of the counterculture, which saw the emergence of the new social movements, also spawned contestatory movements like Fat Liberation

49.- «The Obese», 27. 


\section{G. YÚDICE}

and the politically motivated vegetarianism of Diet for a Small Planet 50. Warren Belasco's history of the Food Revolution in the past two and a half decades recognizes that the powerful food industry ultimately won, in part because of the counterculture's too diffuse means of implementing its utopian visions. As an individualistic politics, it gave way to its own commodification and presented no unified front against the root causes of obesity in America and exploitation of agricultural workers in the third world. There are signs, however, that a coalitional politics is possible. An example is the Institute for Food and Development Policy, which Frances Moore Lappé founded with the profits from her countercultural Diet for a Small Planet. The most recent direction of the institute is to encourage the formation of new social values that, on the one hand, contest the conservative rapaciousness in industry and its attack on civil rights and, on the other, the redefinition of the individual, grounding his/her sense of value not in the isolated person, as proclaimed by Liberal ideology but, rather in the entirety of society. In Rediscovering America's Values, Lappé argues that the privatization of values in the Reagan 80s («fidelity, chastity, saying no to drugsy) have to be re-publicized ${ }^{51}$. Lappé's strategy for recreating public values is of a piece with current progressive agendas: new ways of eroticizing, new ways of articulating needs in pursuit of recognition, valuation, and empowerment. In an age of simulation, these are worthy transformations, our contemporary forms of transcendence.

50.- Cf. «Judy Freespirit and Aldebaran, «Fat Liberation Manifesto», Rough Times (formerly The Radical Therapist), 4, 2 (March-April-May 1974); Aldebaran, «Fat Liberation -a Luxury?» State and Mind, 5 (June-July 1977): 34-38; Alan Dolit, Fat Liberation (Millbrae, CA: 1975); Frances Moore Lappé, Diet for a Small Planet (...).

51.- Frances Moore Lappé, Rediscovering America's Values (New York: Ballantine, 1989). The quote is from an interview with the author: Diana Ketcham, «Author Lappé's plan for planet: Back to basics), The Tribune Calendar (5/28/89). 